
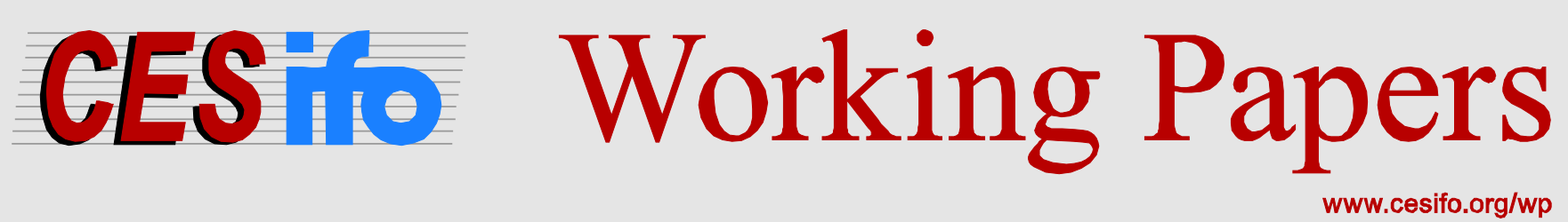

\title{
The Rise of Capitalism and the Roots of Anti-American Terrorism
}

\author{
Tim Krieger \\ Daniel Meierrieks
}

CESIFO WORKING PAPER NO. 4887

CATEgory 2: Public CHOICE

JULY 2014
An electronic version of the paper may be downloaded
- from the SSRN website:
- from the RePEc website:
- from the CESifo website:
wWw.SSRN.com
www.RePEc.org
www.CESifo-group.org/wp

\section{CESifo}




\title{
The Rise of Capitalism and the Roots of Anti-American Terrorism
}

\begin{abstract}
This contribution examines the role of capitalism in anti-American terrorism. Using data for 149 countries between 1970 and 2007, this contribution, contrary to expectations from capitalist peace theory, does not find that Anti-American terrorism increases with external economic liberalization or decreases with higher levels of economic openness. However, consistent with economic norms theory, higher levels of market-capitalism are associated with less anti-American terrorism, whereas the process of marketization fuels it. This suggests that interest groups that have benefitted from the pre-market order deliberately target the USA, where anti-American terrorism serves the purpose of limiting the perceived marketization and Americanization of their communities.
\end{abstract}

JEL-Code: D720, D740, F600.

Keywords: terrorism, anti-Americanism, capitalism, market economy, globalization.

Tim Krieger

Department of Economics

University of Freiburg

Wilhelmstr. $1 b$

Germany - 79085 Freiburg i.Br. tim.krieger@vwl.uni-freiburg.de
Daniel Meierrieks

Department of Economics

University of Freiburg

Wilhelmstr. $1 b$

Germany - 79085 Freiburg i.Br.

daniel.meierrieks@vwl.uni-freiburg.de 


\section{Introduction}

Anti-American terrorism is an important subset of transnational terrorist activity. ${ }^{1}$ As shown in Figure 1, terrorism directed against US interests was a constant threat between 1970 and $2007 .^{2}$ During this time period the USA was the target of terrorist groups with various ideological profiles hailing from both Western countries and the developing world. For instance, US interests were attacked by the left-wing German Red Army Faction (RAF), the Philippine Moro Islamic Liberation Front and the nationalist-separatist Popular Front for the Liberation of Palestine (LaFree, Yang \& Crenshaw, 2009).

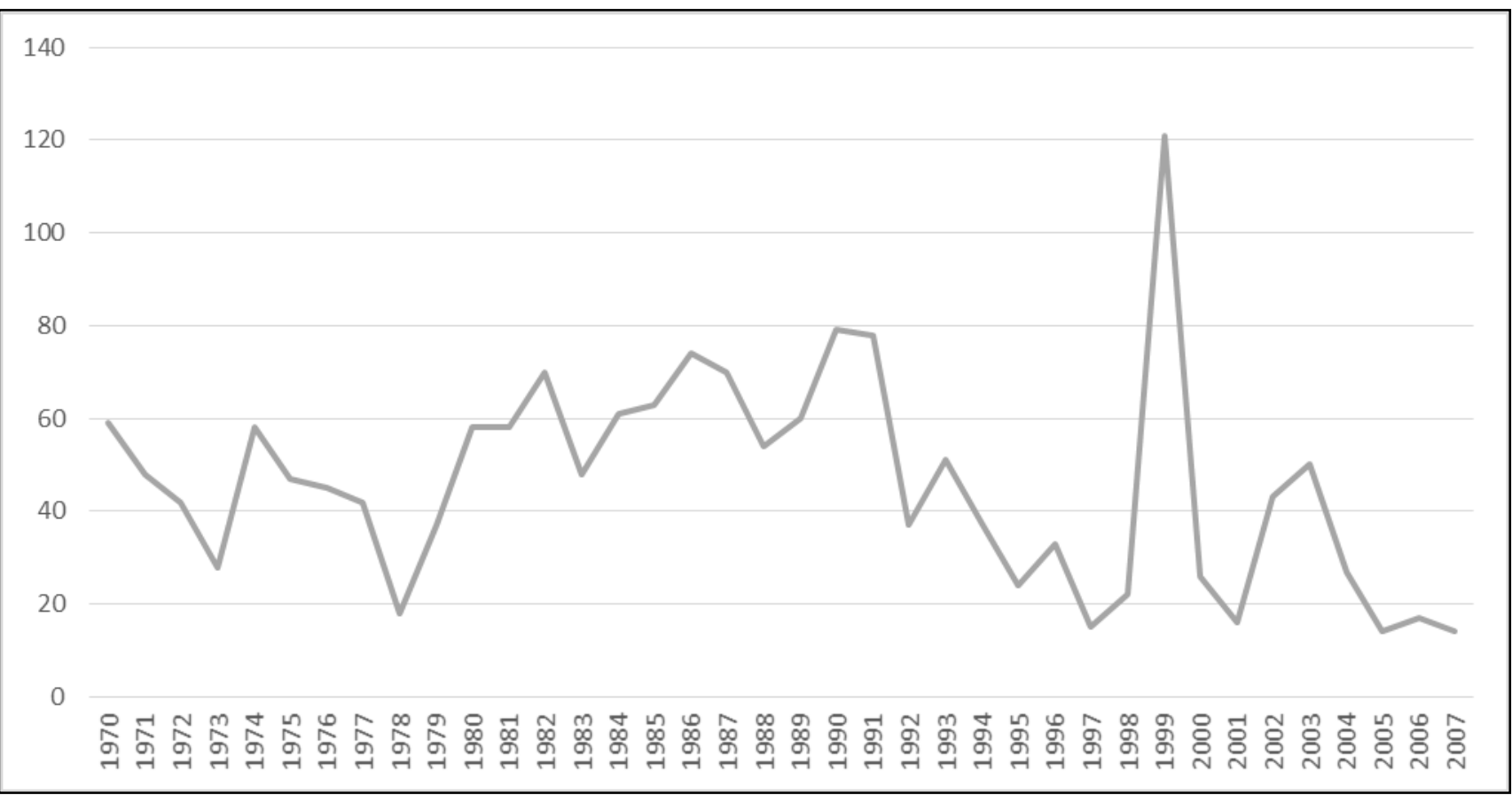

Figure 1: Global Number of Anti-American Terrorist Attacks, 1970-2007

Shortly after the 9/11 attacks, US President George W. Bush (2001) asked: "Why do they [i.e., the terrorists] hate us?" This questions is also at the heart of several academic contributions examining the roots of anti-American terrorism. These studies primarily link its genesis to US foreign policy, i.e., the overall politico-military dominance of the USA in the international system (e.g., Volgy, Imwalle \& Corntassel, 1997; Sobek \& Braithwaite, 2005) and the involvement of the USA in external conflicts, be it through military aid or interventions (e.g., Pape, 2003; Neumayer \& Plümper, 2011).

\footnotetext{
${ }^{1}$ Transnational anti-American terrorism is activity by foreign individuals and groups against US interests (US diplomatic personnel, businesses, embassies, tourists etc.).

${ }^{2}$ The data used to construct this graph are described in Section 3.
} 
In this contribution we study another possible source of anti-American terrorism, the rise of capitalism. Indeed, opposition to capitalism is a cornerstone of many ideologies that have spawned terrorist movements. The anti-capitalist nature of left-wing terrorism seems selfevident. For instance, Varon (2004: 72) describes the motivations of left-wing militancy in the USA and Germany as follows:

"Under the banner of "revolutionary anti-imperialism," Weatherman and the RAF assumed militant roles in an international movement opposing U.S. power and capitalism generally."

This already hints at the close connection between anti-capitalism and anti-Americanism, which is due to the widespread perception of the USA as the "epitome of market civilization" (Mousseau, 2002-2003: 6). For instance, analyzing a survey conducted in France in 2002, Grunberg (2005: 66-67) comes to the following conclusion:

"Traditional anti-Americanism is primarily anticapitalism [...] The United States stands at the heart of the capitalist system, as the prime agent of globalization and its foremost beneficiary."

Importantly, anti-capitalism is not only also associated with left-wing but also nationalistseparatist, anti-colonialist and religious, especially Islamist, terrorist activity directed against the USA. Here, the most prominent example are the 9/11 attacks on the New York World Trade Center, an icon of US economic strength, making the attacks loaded with anti-capitalist symbolism. Further examples are low-profile, recurring attacks in foreign countries on other symbols of US-style capitalism such as subsidiaries of US fast food chains and banks. Here, anticapitalist rhetoric is used to vindicate anti-American violence. For instance, Osama bin Laden explained his fight against the USA in a 2003 statement (BBC, 2003) as follows:

"They [i.e., the American soldiers] only fight for capitalists, usury takers and the merchants of arms and oil, including the gang of crime at the White House."

The discussion so far suggests that hostility towards the USA may also - in addition to US foreign policy — originate from opposition to capitalist development. Motivated by this, in this contribution we provide an empirical examination of the potential nexus between capitalism and anti-American terrorism. In Section 2 we derive hypotheses from two theoretical frameworks (Economic Openness and Economic Norms Theory) that consider such a nexus. Both frameworks contrast the pacifying effects of higher levels of capitalist development (level-effects) with the potentially destabilizing effects of a transition towards capitalism (rate-of-change-effects), but differ with respect to their understanding of what constitutes "capitalism", how "capitalism" may produce pacifying and destabilizing effects, how "capitalism" can be operationalized in empirical analyses and how, ultimately, policymakers can harness the beneficial and contain the inflammatory effects of "capitalism". In Section 3 we describe the variables and methodology used to statistically examine the hypotheses developed in Section 2, employing country-level panel data for 149 countries between 1970 and 2007. Section 4 discusses our findings. Section 5 
provides further time-series evidence, where we analyze the relationship between capitalism and anti-American terrorism on the system-level. Section 6 concludes.

\section{Capitalism and the Origins of Anti-American Terrorism}

\subsection{Economic Openness and Anti-American Terrorism}

A number of empirical contributions have found that capitalist countries are less likely to experience interstate and intrastate conflict (e.g., Gartzke, 2007; De Soysa \& Fjelde, 2010; for reviews of the literature see Schneider \& Gleditsch, 2010; Schneider, 2014). They thus offer empirical support for the "peace-through-capitalism thesis" (Schneider \& Gleditsch, 2010: 108). Importantly, these studies generally “equate 'capitalism' with free markets or smaller governments at home and abroad" (Mousseau et al., 2009: 80). Using this definition of capitalism, the "classical" capitalist peace literature offers several pathways through which capitalism may be conducive to peace. First, economic openness may stimulate economic growth and development, consequently raising the opportunity costs of conflict (Schneider, 2014). Second, openness creates economic interdependencies, e.g., through trade, capital movements or the international division of labor (Schneider, 2014). Such linkages make it less attractive to engage in conflict because the negative economic consequences of an attack are likely to backfire on the attacker. What is more, evidence by Hegre (2000) suggests that the beneficial effects of economic interdependence increase with the level of economic development (e.g., due to higher trade volumes and lower transaction costs), making it even less attractive for highly developed economies with open markets to attack each other.

In line with this discussion, we can hypothesize that capitalist economies-understood as economies with free and open (external) goods and capital markets-are also less likely to produce anti-American terrorism. In particular, it ought to be less likely that citizens or subnational (terrorist) groups from countries with similarly high levels of capitalist development attack interests of the USA, the main proponent of modern capitalism. We also expect foreign governments to be more reluctant to permit or even sponsor anti-American terrorism when their own economies are capitalistically organized. This is because there tends to be a close economic interdependence between the USA and other capitalist countries and the benefits associated with such interdependencies tend to be particularly large. Anti-American terrorism ought to be a particularly expensive venture when it originates from developed capitalist societies. This leads to our first hypothesis:

Hypothesis (Hla): A higher level of external economic openness is associated with less anti-American terrorism (level-effect).

The previous discussion suggests that capitalist development (defined as external economic openness) should have pacifying effects. In a recent overview of the capitalist peace literature, Schneider (2014), however, points out that such ideas do not sufficiently contrast the beneficial level-effects of economic globalization with potentially inflammatory rate-of-change-effects, i.e., 
effects associated with the process of economic liberalization. While economic theory suggests that openness is ultimately beneficial, economic liberalization may also have serious distributional consequences (Schneider, 2014). Considering trade in goods, e.g., liberalization may reduce labor demand (and possibly, wages) in the agricultural sector in favor of the modern industrial sector. Similarly, increased financial openness may benefit capital-intense industrial development at the expense of increased vulnerability of other economic sectors to the sudden inflow/outflow of international capital. Ultimately, some segments of society are likely to experience negative economic effects due to the globalization process, e.g., in the form of poverty, socio-economic insecurity and unemployment (Stiglitz, 2005).

In other words, irrespective of the ultimate gains associated with economic integration, external economic liberalization may antagonize various segments of society that lose during this process. Indeed, Bussmann \& Schneider (2007) find that trade and financial liberalization tend to increase the risk of civil war, potentially due to the redistributive struggle associated with external liberalization. Important to our study, the losers of economic globalization may also resort to anti-American terrorist activity due to increased economic vulnerability and further substantial distributional effects accompanying the transition process. Especially when it is directed against the USA, terrorism signals discontent with the liberalization process and may even initiate an anti-market rollback. This leads to our second hypothesis:

Hypothesis (H2a): External economic liberalization is associated with more antiAmerican terrorism (rate-of-change-effect).

\subsection{Economic Norms Theory and Anti-American Terrorism}

Another theoretical framework that links capitalist development to the emergence of inter- and intrastate violence is the so-called economic norms theory or "social market-capitalist peace" theory. This framework has been developed by Mousseau and his co-authors in a series of theoretical and empirical contributions (e.g., Mousseau, 2002-2003, 2009, 2011, 2012, 2013; Mousseau \& Mousseau, 2008; Mousseau et al., 2013). Importantly, economic norms theory defines capitalism "as a way of life: the extent to which citizens in a society regularly contract with strangers located in a market to obtain goods, services and incomes" (Mousseau et al., 2013: 80-81). In contrast to the classical capitalist peace literature, the market-capitalist understanding of capitalism does not imply open markets with little government regulation. Rather, market-capitalist development (i.e., high contract-intensity) may go hand in hand with low economic openness and/or strong government regulation (e.g., in Scandinavia).

Economic norms theory posits that conducting economic transactions via markets and contracting produces a specific set of norms and values. As stressed by Mousseau (2012: 476):

"[I]ndividuals [who are] routinely dependent on trusting strangers in contract will develop the habits of trusting strangers and preferring universal rights, impartial law, and liberal democratic government." 
The (liberal) norms and values associated with market-capitalism (e.g., cooperation, tolerance, equity) in turn produce outcomes conducive to peace (e.g., economic development, sound institutions) and create a common interest in peace between market-capitalist economies.

Empirical investigations of the economic norms theory indeed find that higher levels of marketcapitalist development foster interstate and intrastate peace (e.g., Mousseau, 2009, 2012, 2013; Mousseau et al., 2013; for a critical discussion of the evidence see Dafoe, Oneal \& Russett, 2013).

The associated transmission channels may also matter to the emergence of anti-American terrorism. The values embedded in market-capitalism tend to lower the overall acceptance of the use of violence to voice dissent and achieve change. This may also make violence against American interests less attractive in market-capitalist societies. Shared values also create fewer opportunities to rally support for terrorism by exploiting cultural or identity differences. Rather, the USA may be perceived as a cultural-economic role model by large parts of other marketcapitalist societies' populations. Ultimately, anti-American terrorism may therefore hurt the terrorists' cause, e.g., by negatively affecting mobilization. For instance, this may explain the very limited popular support for anti-American terrorist groups in Western Europe.

Liberal values also lead to the creation of liberal institutions. For instance, Mousseau (20022003) and Mousseau \& Mousseau (2008) argue that impersonal contractual exchange-a main feature of market economies - leads a strong rule of law, persistent democratic institutions and sound property rights protection. Such developments make violence less attractive (i.e., less costefficient), be it by offering non-violent means of conflict resolution and redistribution or making it more difficult to organize political violence as state capacity increases. Consequently, they also make violence against American interests less attractive in market-capitalist societies.

Furthermore, market-capitalism means "a positive sum game: any improvement in the welfare of anyone else in the market increases the odds that one's own welfare will improve" (Mousseau, 2012: 472). Domestic and international market growth thus promote economic development for all market-capitalist economies, while conflict between market-capitalist economies coincides with economic losses for all of them. Conflict with the USA, the most important marketcapitalist economy, is thus particularly unattractive. Attacking the USA by means of terrorism or its sponsoring by governments cannot be in the interest of the citizens and governments of other market-capitalist economies, given that the opportunity costs of conflict are prohibitively high. This idea is also supported by Mousseau (2009) who finds that not a single fatal conflict occurred between market-capitalist economies between 1961 and 2001.

In sum, economic norms theory suggests that market-capitalist economies have little incentive to fight each other. Rather, as argued in Mousseau (2009: 82):

"[S]tates with contract intensive economies [...] perceive common security interests in defending the global status quo and are in natural alliance against any state or nonstate entity that seeks to challenge it" 
This is due to a common economic way of life and associated contractualist values that societies with a similar level of market-capitalist development share, resulting in shared interests in market growth, economic development and liberal politico-economic institutions. These factors make the emergence of anti-American terrorism in market-capitalist economies less likely, leading to our next hypothesis:

Hypothesis (H1b): A higher level of market-capitalist development is associated with less anti-American terrorism (level-effect).

The rise of market-capitalism, however, also implies the decline of clientalism. Clientalism can be understood as the inverse of market-capitalism and means that "the market is comparatively peripheral to everyday life as many individuals depend partially or wholly not on the market, but instead on social networks [to perform economic transactions]" (Mousseau 2012: 472). These networks - be they in the form of, e.g., political parties, criminal groups or tribal clans - are controlled by the traditionally wealthy and powerful such as political party officials, crime lords or tribal chiefs. Given that the advent of market-capitalism allows for more efficient economic transactions that rely on (impersonal) contracting, the marketization process, i.e., the transition from a clientalist to a market-capitalist economy ${ }^{3}$, may be source of conflict and anti-American terrorism due to the decline of clientalism and the associated threat to the clout of the "patrons and their lieutenants who hold privileged positions in the old clientalist hierarchies" (Mousseau, 2002-2003: 19).

Clientalism provides the traditional elite with politico-economic rents (e.g., from controlling artificial monopolies, see Kirk, 1983), which are endangered once marketization starts. The elite may consequently turn to terrorism for two reasons. First, they may use terrorism as a means to voice dissent with existing developments - the decline of clientalism — so as to curtail domestic marketization. Here, the USA is a natural target to promote such policy change. Second, terrorism may create new politico-economic rents which may offset losses due to the rise of market-capitalism and thus consolidate the elite's societal position. As shown by Kirk (1983), such rents are routinely obtained by terrorist groups through the use of violence, making terrorism a rational action for (parts of) the elite to change the distribution of resources in their favor. As such, anti-American resentment organized by the traditional elite can be understood as a rational response to the negative distributional consequences (i.e., the loss of politico-economic influence) of marketization. The elite's client base may also benefit from the rents terrorism creates. The clientele may pledge loyalty to rent-capturing terrorist groups led by powerful patrons, which provide them — as another form of clientalism — with mental and material rewards

\footnotetext{
${ }^{3}$ Commonly, countries are either already heavily market-capitalist or have some mixture of clientalism and markets. The latter is particularly true for developing countries. Marketization then more precisely refers to the situation where market-capitalism becomes comparatively more important in mixed clientalist-capitalist economies.
} 
(e.g., identity, employment) in return. ${ }^{4}$ Indeed, Mousseau (2011) finds that support for Islamist terrorism is particularly strong among the urban poor-a population group that has obviously not benefited from the marketization process - in developing countries. Here, anti-American terrorism can be a particularly powerful method for terrorist leaders to attract and maintain loyal followers as it "reflects the leader's power [and] taps into widespread antimarket fury [shared by the terrorist leaders and their clientele]" (Mousseau, 2002-2003: 20).

The marketization process is not only dangerous to the traditional elite and their clientele by inducing sweeping economic change (e.g., rural-urban migration, industrialization). As argued above, market-capitalism promotes liberal values (equity, tolerance, religious freedom etc.). Through the process of globalization these liberal values (e.g., in the form of women's and human rights) spread to the non-Western world (Neumayer \& De Soysa, 2007; Dreher, Gassebner \& Siemers, 2012). The cultural change associated with the rise of market-capitalism may consequently also antagonize traditionalist and religious segments of society and cause antiAmerican resentment. As summarized by Cronin (2003: 45):

"[The] United States is projecting uncoordinated economic, social, and political power even more sweepingly than it is in military terms. Globalization, in forms including Westernization, secularization, democratization, consumerism, and the growth of market capitalism, represents an onslaught to [...] conservative cultures repelled by the fundamental changes that these forces are bringing $[\ldots]$ ”.

The "import" of Western ideas is likely to undermine the politico-economic influence of the traditionalist and religious, given that these ideas propagate an attractive alternative lifestyle. Anti-American terrorism may therefore be a rational choice for traditionalists, so as to limit the cultural modernization that accompanies the transition towards a market economy. Here, any terrorist attack against the USA can be seen as a symbolic attack against modernity and the Western way of life perceived to be projected onto traditionalist societies by the USA.

In summary, irrespective of the ultimate gains associated with market-capitalist development discussed above, marketization causes comprehensive economic-cultural change that is likely to antagonize those societal groups that have benefitted from pre-market social conditions, i.e., from clientalism and traditionalism. These groups may resort to violence to counter the marketization process, where anti-American terrorism may be a particularly effective form of violence due to the strength it signals and the anti-market and anti-modernization imagery it carries, which may ultimately contribute to a rollback of pro-market developments. This leads to our final hypothesis:

Hypothesis (H2b): The marketization process is associated with more anti-American terrorism (rate-of-change-effect).

\footnotetext{
${ }^{4}$ It seems reasonable to assume that the elite provides the terrorist leaders, while their client base (i.e., the poor and otherwise economically vulnerable) provides the foot soldiers and supporters.
} 


\section{Data and Methodology}

To empirically test the hypotheses outlined above, we compile data on terrorism, capitalist development and further controls for a panel of 149 countries for the period between 1970 and 2007. The summary statistics and a country list are reported in the appendix.

\subsection{Dependent Variable}

We indicate anti-American terrorism by the number of terrorist attacks by citizens of another country against US targets. Here, we use the source definition of anti-American terrorism, where an attack is assigned to the country of origin of the perpetrator, irrespective of the actual location of the attack. For instance, the 1988 bombing of a US military recreational club in Naples (Italy) by the Japanese Red Army is then assigned to Japan.

The data come from the International Terrorism: Attributes of Terrorist Events (ITERATE) dataset (Mickolus et al., 2008). ITERATE is the most widely used dataset covering transnational terrorism due to its consistent coding of terrorist events, where coding is done according to information gathered from the world's newsprint and electronic media. ITERATE defines terrorism as the use (or threat thereof) of anxiety-inducing, extra-normal violence for political purposes by non-state individuals or groups, where the intention of such action is to influence a target group wider than the immediate victims (Mickolus et al., 2008). ITERATE excludes terrorist attacks against combatants associated with declared wars, military interventions or guerilla warfare against military targets (Mickolus et al., 2008).

\subsection{Main Explanatory Variables}

As discussed above, the two frameworks linking capitalism to anti-American terrorism considered in this contribution rely on different understandings of "capitalism". For our empirical analysis we therefore use different indicators to operationalize it, depending on which hypothesis we want to examine.

To capture the effect of capitalism understood as external economic openness on anti-American violence, we use the KOF Index of Economic Globalization drawn from a recent update of Dreher (2006). This variable is a composite indicator that captures various aspects of economic globalization. It includes information on trade and capital openness, both of which are relevant to the globalization process. For one, the index considers actual trade and capital flows (e.g., exports/imports of goods and services, foreign direct investment) and, for another, the regulations associated with trade and capital openness (e.g., trade tariffs, capital controls). A higher value of the index characterizes an economy that is more externally open and less regulated. Consistent with $H \mathrm{la}$, we expect a higher level of the index to correlate with less antiAmerican terrorism. However, from $H 2 a$ it follows that the liberalization process (i.e., the rateof-change-effect indicated by the annual change in the KOF index) ought to coincide with more anti-American violence.

To capture the effect of capitalism understood as social market-capitalism on anti-American terrorism, we follow the economic norms theory literature (e.g., Mousseau, 2002-2003, 2009, 
2011, 2012, 2013; Mousseau \& Mousseau, 2008; Mousseau et al., 2013) and consider economies to be market-capitalist when most citizens regularly obtain goods and services by contracting with strangers in a market. As in the aforementioned studies, we operationalize the level of market-capitalism by using annually aggregated data on per capita life insurance contracts in force in (logged) constant US dollars. The data on life insurance are drawn from the most recent update (Version 2.0) of the Contract Intensity of National Economies Dataset (Mousseau, 2012). Mousseau (2012) argues that life insurance data reasonably well reflects the overall intensity of market institutionalization because life insurance contracts are purely impersonal and credibility in commitments therefore rests only on third party enforcement. A large volume of per capita life insurance contracts in force tends to signal that a society largely relies on (impersonal) means of contracting and contract enforcement and less on social relationships (e.g., between the patron and his clientele) to conduct economic transactions. In line with $H 1 b$, we expect a higher level of market-capitalism to be negatively related to anti-American terrorism. The transition towards market-capitalism is operationalized by the annual change in per capita life insurance contracts. From $\mathrm{H} 2 b$ we expect a transition towards market-capitalism to coincide with more antiAmerican terrorism.

The levels of economic openness (measured by the KOF index) and market-capitalism (measured by the life insurance data) correlate rather strongly with each other $(r=0.68) .{ }^{5}$ As shown in Figure 2, both the levels of economic globalization and market-capitalism in the USA in 1970 were markedly above the global average. Considering the change in these capitalism measures over time, both the USA and the rest of the world saw a rather steady movement towards higher levels of capitalist development, with the rest of the world slightly converging to American levels of capitalist development. Yet, in 2007 the US level of capitalist development both in terms of external economic openness and market-capitalism was still substantially higher than the global average. Overall, these stylized facts suggest that the USA could indeed be considered a figurehead of globalization and marketization, offering further reason to hypothesize that the USA is deliberately targeted due to its (perceived) role in globalization and the rise of capitalism.

5 However, the correlation is far from perfect. There are many countries that are fairly economically open but not strongly market-capitalist (e.g., Angola, Oman, Nigeria and Bolivia). The reverse is also true. For instance, Japan is a market-capitalist country since the 1960s, while its level of economic openness was still well below the global average in the 2000s. 


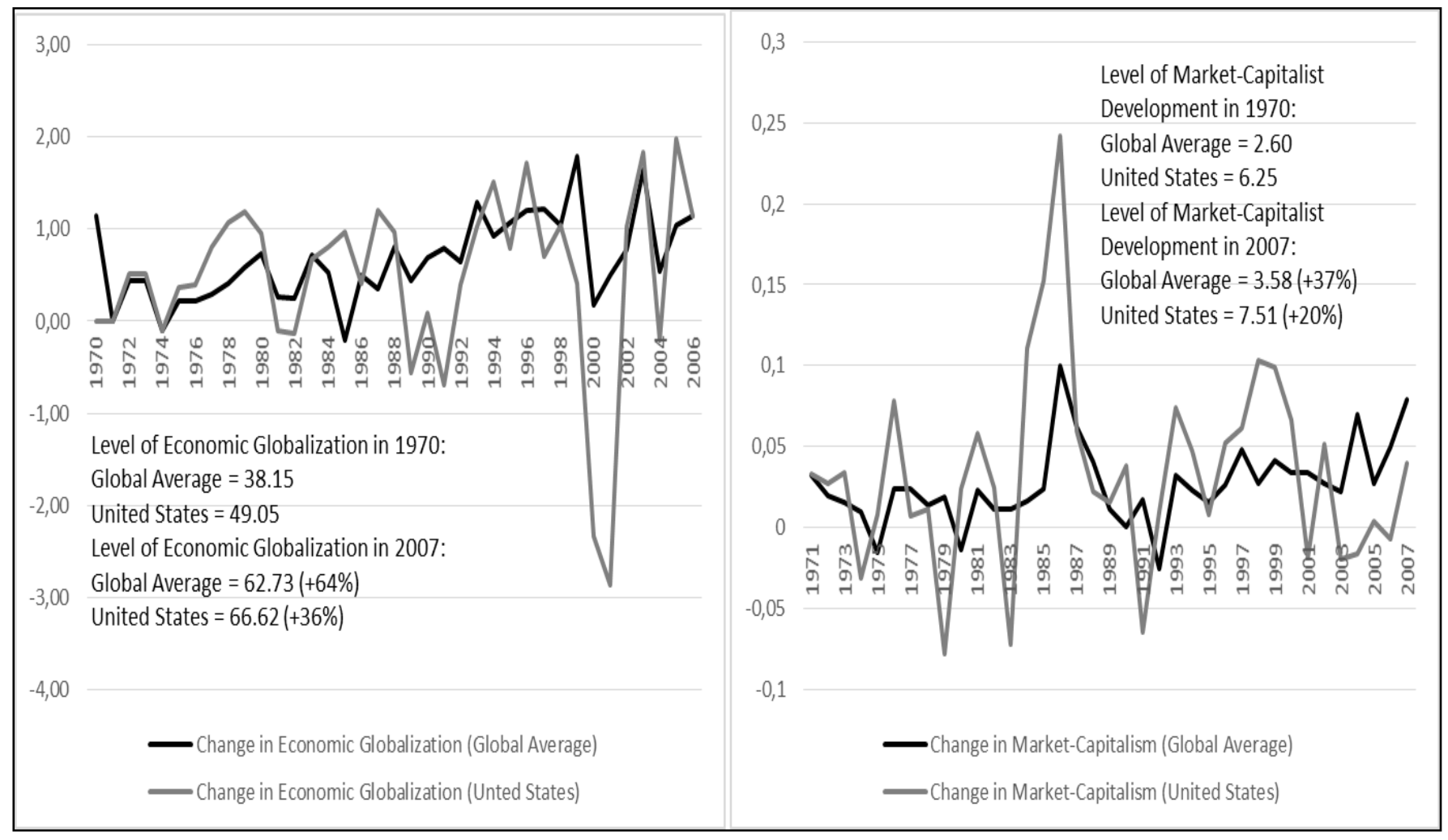

Figure 2: Global and US Change in Capitalist Development, 1970-2007

As shown in Table 1, the levels of both capitalism measures strongly correlate with important development outcomes. ${ }^{6}$ Higher levels of these variables coincide with higher regulatory quality (linked to sound policies that promote private sector development), a stronger rule of law, lower levels of corruption, reduced economic significance of the agricultural sector, higher levels of urbanization and lower fertility rates. The same is true when we consider the correlation between these development outcomes and the change in market-capitalist development (i.e., marketization). However, the correlation between them and the change in economic openness (i.e., external economic liberalization) is less pronounced.

Overall, this suggests that higher levels of capitalist development-however measured - indeed correlate with socio-economic and institutional outcomes (as indicated by, e.g., a strong rule of law, inclusive economic institutions, declining fertility and urbanization) which ultimately ought to make anti-American terrorism less attractive ( $H 1 a$ and $H 1 b)$. At the same time, however, the correlation between changes in capitalist development - especially considering marketizationand these development outcomes hints at the adjustment costs that accompany the transition towards a capitalist economy, which may very well fuel anti-American resentment $(H 2 a$ and $H 2 b$ ). For instance, anti-American terrorism may be a consequence of economic modernization accompanying marketization and economic liberalization. Here, the negative association

\footnotetext{
${ }^{6}$ Due to data limitations we only present findings for the year 2000. However, we have no reason to believe that our findings would differ had we used data for other time periods.
} 
between measures of capitalist development and agricultural sector importance and the positive association of them with urbanization can be interpreted as indicating such change (e.g., in the form of rural-urban migration).

\begin{tabular}{|c|c|c|c|c|}
\hline & $\begin{array}{l}\text { Level of } \\
\text { Market- } \\
\text { Capitalism }\end{array}$ & $\begin{array}{l}\text { Change in } \\
\text { Market- } \\
\text { Capitalism } \\
\text { (1996-2000 } \\
\text { Average) } \\
\end{array}$ & $\begin{array}{l}\text { Level of } \\
\text { Economic } \\
\text { Globalization }\end{array}$ & $\begin{array}{l}\text { Change in } \\
\text { Economic } \\
\text { Globalization } \\
\text { (1996-2000 } \\
\text { Average) }\end{array}$ \\
\hline $\begin{array}{l}\text { Regulatory } \\
\text { Quality }\end{array}$ & $0.78 * * *$ & $0.38 * * *$ & $0.77 * * *$ & 0.12 \\
\hline Rule of Law & $0.84 * * *$ & $0.38 * * *$ & $0.73^{* * *}$ & 0.11 \\
\hline $\begin{array}{l}\text { Control of } \\
\text { Corruption }\end{array}$ & $0.84 * * *$ & $0.37 * * *$ & $0.73^{* * *}$ & 0.07 \\
\hline $\begin{array}{l}\text { Value Added in } \\
\text { Agriculture }\end{array}$ & $-0.59 * * *$ & $-0.35 * * *$ & $-0.69 * * *$ & -0.04 \\
\hline Urbanization & $0.63 * * *$ & $0.23 * * *$ & $0.65^{* * *}$ & 0.01 \\
\hline Fertility Rate & $-0.61 * * *$ & $-0.41 * * *$ & $-0.60 * * *$ & $-0.29 * * *$ \\
\hline
\end{tabular}

Notes: Pearson's correlation coefficients reported. (***) indicates statistical significance at 0.01. Institutional data obtained from the Worldwide Governance Indicators of the World Bank (http://info.worldbank.org/governance/wgi/sc_country.asp). Other variables drawn from the WDI. All data for the year 2000 if not indicated otherwise.

\section{Table 1: Pairwise Correlation between Indicators of Capitalist Development and Assorted Development Outcomes}

\subsection{Control Variables}

To avoid detecting spurious effects of market-capitalist development on anti-American terrorism, we follow Neumayer \& Plümper (2011) by including in our baseline model control variables for population size, geographical distance to the USA, per capita income, democracy and military dependence from the USA. This speaks to the idea that the origins of anti-American terrorism may also lie in non-capitalism factors.

Data for (logged) population size are drawn from the PENN World Table (Heston, Summers \& Aten, 2009). More populous countries ought to experience more anti-American attacks due to the existence of a larger pool of (potential) terrorists, terrorist supporters and American victims. Indeed, previous research has found population size to be a robust predictor of terrorism (Krieger \& Meierrieks, 2011). 
Data for geographical distance to the USA come from the CEPII GEODist Database (Mayer \& Zignago, 2011). Distance is indicated by the (logged) distance between Washington, DC, and the respective foreign country's capital. Neumayer \& Plümper (2011) argue that the likelihood of an anti-American attack ought to decrease with distance, given that it increases the material costs of attacking.

The PENN World Table also provides data on (logged) real per capita income. Possibly, richer countries generate less terrorism, as it becomes less attractive to participate in terrorism when opportunities for non-violent economic participation abound. Yet, richer countries are also militarily stronger and therefore more likely to prevent insurgents with anti-market and antiAmerican agendas from capturing territory. Consequently, insurgents in richer countries may resort to terrorism (as an open rebellion with territorial control becomes prohibitively costly). This may result in a positive relationship between terrorism and economic development, as previously found by Sanchez-Cuenca \& De La Calle (2012). Given these conflictive lines of reasoning, we remain agnostic about the expected effect of economic development on antiAmerican terrorism.

The Democracy and Dictatorship Revisited Dataset of Cheibub, Gandhi \& Vreeland (2010) provides a dichotomous measure of democracy (taking into account the presence of opposition parties, free elections etc.). Krieger \& Meierrieks (2011) argue that, for one, respect for civil liberties may make democracies more vulnerable to terrorism because this respect may restrict counter-terrorism efforts. However, they also suggest that the possibility to peacefully achieve change - e.g., in terms of curtailing US influence and the spread of capitalism - in democracies may reduce the need for terrorism, thus making democracies actually less vulnerable to terrorism. Given these conflicting ideas, we also remain agnostic about the expected effect of democracy on anti-American terrorism.

Finally, we consider the effect of military dependence from the USA on anti-American terrorism. It is measured by the (logged+1) ratio of domestic military spending to US military assistance. This variable is constructed using data on US military aid from USAID (2013) and a recent update of the National Material Capabilities Dataset (Singer, 1988). Neumayer \& Plümper (2011) find that countries that receive high amounts of US military aid relative to their own military capacity are more likely to generate anti-American terrorism. They argue that terrorist groups, even if they ultimately have domestic ambitions, nevertheless attack the foreign sponsor of a domestic government (e.g., the USA) to stir up domestic popular support for their cause and improve terrorist mobilization. They also argue that anti-American terrorism may weaken the local government that is militarily dependent on the USA, given that US support is likely to decrease with terrorism directed against it (as anti-American terrorism means higher costs of military supporting a foreign country). ${ }^{7}$

\footnotetext{
${ }^{7}$ As suggested by a referee, an interesting avenue of future research could be to employ network techniques (see also Schneider, 2014 for a discussion of some merits of network analyses) as an alternative method to consider the (complex) multilateral phenomenon of transnational terrorism.
} 
As a robustness check, we consider two additional variables which have also been suggested as potential terrorism determinants (Piazza, 2008; Krieger \& Meierrieks, 2011). We control for a country's experience with state failure and its government size. ${ }^{8}$ Data on state failure come from the Political Instability Taskforce ${ }^{9}$, while data on government size are drawn from the PENN World Table.

\subsection{Empirical Methodology}

To test our hypotheses, we run a series of negative binomial regressions, given that our dependent variables are overdispersed (i.e., their variances are larger than their means) count data. ${ }^{10}$ Negative binomial regressions are commonly used in studies assessing the determinants of terrorism (e.g., Krieger \& Meierrieks, 2011; Neumayer \& Plümper, 2011). All time-variant explanatory variables enter the model in lagged form to minimize endogeneity. ${ }^{11}$ Time dummies are included in all estimations to address unit effects and the trending of transnational terrorism over time.

\section{Negative Binomial Regression Results}

The negative binomial regression results are reported in Table 2. With respect to the main explanatory variables of interest, we find no evidence that external economic openness (indicated by the KOF index) substantially correlates with anti-American terrorism, neither with respect to the level of openness nor the economic liberalization process. That is, we find no support for $H I a$ and $H 2 a$. By contrast, we find that a higher level of market-capitalist development (indicated by life insurance contract-intensity) is associated with less anti-American terrorism in

For instance, such an approach may help to analyze how alliances between the USA and other countries shape the flow of aid and transnational terrorism between them.

${ }^{8}$ Introducing further controls to our estimation model (indicating political proximity to the USA, economic growth, population growth, domestic military capacity, primary goods exports, ethnic fractionalization, Muslim population share, a country's dependence on fuel exports and regime age) does not affect our main findings. These additional robustness checks are available upon request.

${ }^{9} \mathrm{http}$ ://globalpolicy.gmu.edu/political-instability-task-force-home/pitf-problem-set-annual-data.

${ }^{10} \mathrm{We}$ also run zero-inflated negative binomial (ZINB) regressions for all specifications reported below. ZINB regressions can be appropriate to accommodate for the fact that there are many zeroes (i.e., no anti-American terrorism) in country-cases and the possibility of a reporting bias associated with them (Neumayer \& Plümper, 2011: 13). Our ZINB regression results are consistent with the estimates from conventional negative binomial regressions reported in the main text and available upon request.

11 As suggested by a referee, the capitalist orientation of a society may be an endogenous variable. Lagging the explanatory variables may not be sufficient to overcome this problem. Unfortunately, at the moment there is no sound instrumental variable available to account for this especially with time-series cross-sectional data. We thus invite future research to investigate the potentially complex relationship between capitalist development and political instability with alternative statistical approaches such as instrumental-variable or Granger causality analyses. 
statistically significant ways, while the marketization process is associated with more antiAmerican terrorism. These findings are in line with $H 1 b$ and $H 2 b$.

Notably, the pacifying and inflammatory effects of market-capitalism (as indicated by the incidence-rate-ratios (IRR) reported in Model 8 in Table 2) are both substantive. According to the IRR, a one-unit increase in the level of market-capitalism (change in market-capitalism) is associated with a 36 percent decrease (68 percent increase) in anti-American terrorism. By contrast, the effects of economic openness do not only lack statistical significance, but also economic substantiveness, as indicated by IRR that are close to unity.

Our findings are thus consistent with predictions derived from the economic norms theory framework (e.g., Mousseau, 2002-2003, 2009, 2011, 2012, 2013; Mousseau \& Mousseau, 2008; Mousseau et al., 2013). Anti-American terrorism is less likely to originate from countries that are similarly market-capitalistically developed as the USA. With the USA these countries share interests in international market growth, economic development and the expansion and persistence of liberal-democratic institutions (e.g., a strong rule of law) that underpin the presentday global status quo favorable to them. Market-capitalist countries - their governments and citizens - have no interest in attacking the most important market-capitalist economy. Rather, anti-American terrorism is discouraged, be it because it produces economic losses (by shrinking the international market) or because it is particularly cost-inefficient (e.g., as institutions inhibit the use of violence to foster political change).

Our finding that the marketization process increases the likelihood of anti-American terrorism is also consistent with economic norms theory. The rise of market-capitalism coincides with the decline of clientalism and traditionalism. This means that marketization tends to unfavorably affect the economic and politico-cultural influence of certain population segments (the old elite and their economically vulnerable clientele, traditionalists and the religious) that have benefitted from the pre-market clientalist-traditionalist order of society. As argued in, inter alia, Mousseau (2002-2003), the losers of marketization may intentionally target the USA to effectively voice dissent and rollback pro-market developments by punishing the USA for its perceived role in capitalism, globalization and the Americanization of their societies (e.g., in the form of women empowerment, secularization and consumerism). In so doing, the losers of the transition process may be able to consolidate their societal position. 


\begin{tabular}{|c|c|c|c|c|c|c|c|c|}
\hline & $(1)$ & (2) & (3) & (4) & $(5)$ & $(6)$ & $(7)$ & (8) \\
\hline Market-Capitalist & -0.329 & -0.346 & -0.273 & & & & -0.439 & 0.644 \\
\hline Development (Level-Effect) ${ }_{t-1}$ & $(0.112) * * *$ & $(0.115)^{* * *}$ & $(0.110)^{* *}$ & & & & $(0.114)^{* * *}$ & $(0.073) * * *$ \\
\hline Market-Capitalist & 0.446 & 0.472 & 0.414 & & & & 0.520 & 1.683 \\
\hline Development (Rate-of-Change-Effect) ${ }_{t-1}$ & $(0.206) * *$ & $(0.207)^{* *}$ & $(0.205)^{* *}$ & & & & $(0.211)^{* *}$ & $(0.356)^{* *}$ \\
\hline Economic Globalization & & & & -0.015 & -0.017 & -0.011 & -0.004 & 0.996 \\
\hline$(\text { Level-Effect })_{t-1}$ & & & & $(0.011)$ & $(0.011)$ & $(0.011)$ & $(0.010)$ & $(0.010)$ \\
\hline Economic Globalization & & & & -0.001 & -0.001 & 0.001 & -0.016 & 0.984 \\
\hline (Rate-of-Change-Effect) ${ }_{t-1}$ & & & & $(0.024)$ & $(0.025)$ & $(0.025)$ & $(0.025)$ & $(0.025)$ \\
\hline \multirow[t]{2}{*}{ Population Size $_{t-1}$} & 0.643 & 0.672 & 0.613 & 0.672 & 0.682 & 0.645 & 0.709 & 2.032 \\
\hline & $(0.093)^{* * *}$ & $(0.099) * * *$ & $(0.091)^{* * *}$ & $(0.098) * * *$ & $(0.103)^{* * *}$ & $(0.101)^{* * *}$ & $(0.103)^{* * *}$ & $(0.209) * * *$ \\
\hline \multirow[t]{2}{*}{ Distance to the USA } & -0.123 & -0.119 & -0.126 & -0.066 & -0.070 & -0.058 & -0.063 & 0.939 \\
\hline & $(0.197)$ & $(0.184)$ & $(0.182)$ & $(0.119)$ & $(0.122)$ & $(0.101)$ & $(0.105)$ & $(0.099)$ \\
\hline \multirow[t]{2}{*}{ GDP p.c. $t-1$} & 0.751 & 0.794 & 0.800 & 0.566 & 0.606 & 0.657 & 0.951 & 2.588 \\
\hline & $(0.190)^{* * *}$ & $(0.196)^{* * *}$ & $(0.189)^{* * *}$ & $(0.179) * * *$ & $(0.174) * * *$ & $(0.201)^{* * *}$ & $(0.212)^{* * *}$ & $(0.549)^{* * *}$ \\
\hline \multirow[t]{2}{*}{ Democracy $_{t-1}$} & -0.040 & 0.043 & -0.042 & 0.019 & 0.036 & -0.060 & 0.227 & 1.255 \\
\hline & $(0.235)$ & $(0.222)$ & $(0.224)$ & $(0.226)$ & $(0.226)$ & $(0.218)$ & $(0.230)$ & $(0.288)$ \\
\hline Military Dependence & 0.257 & 0.247 & 0.253 & 0.335 & 0.330 & 0.351 & 0.287 & 1.332 \\
\hline from the USA ${ }_{t-1}$ & $(0.054) * * *$ & $(0.052)^{* * *}$ & $(0.058)^{* * *}$ & $(0.055) * * *$ & $(0.054) * * *$ & $(0.057)^{* * *}$ & $(0.057) * * *$ & $(0.075)^{* * *}$ \\
\hline \multirow[t]{2}{*}{ Government Size $_{t-1}$} & & 0.021 & & & 0.011 & & & \\
\hline & & $(0.012)^{*}$ & & & $(0.011)$ & & & \\
\hline \multirow[t]{2}{*}{ State Failure $_{t-1}$} & & & 0.273 & & & 0.270 & & \\
\hline & & & $(0.056)^{* * *}$ & & & $(0.058)^{* * *}$ & & \\
\hline No. of Observations & 4576 & 4576 & 4571 & 4277 & 4277 & 4272 & 4218 & 4218 \\
\hline No. of Countries & 149 & 149 & 149 & 136 & 136 & 136 & 136 & 136 \\
\hline Mean VIF & 1.71 & 1.65 & 1.65 & 1.48 & 1.47 & 1.45 & 1.88 & 1.88 \\
\hline Wald $\chi^{2}$ & 371.99 & 369.80 & 464.89 & 357.09 & 364.83 & 490.95 & 384.62 & 384.62 \\
\hline$\left(\right.$ Prob. $\left.>\chi^{2}\right)$ & $(0.00) * * *$ & $(0.00) * * *$ & $(0.00)^{* * *}$ & $(0.00)^{* * *}$ & $(0.00) * * *$ & $(0.00) * * *$ & $(0.00) * * *$ & $(0.00) * * *$ \\
\hline Log-Pseudolikelihood & -2374.38 & -2368.61 & -2336.21 & -2118.60 & -2117.34 & -2090.40 & -2087.35 & -2087.35 \\
\hline
\end{tabular}

Table 2: Capitalist Development and Anti-American Terrorism 
Briefly considering the baseline controls, our findings for them are robust across different specifications. First, we find that anti-American terrorism is positively associated with population size. Presumably, this is due to a scale effect, e.g., as larger populations coincide with larger pools of terrorists, terrorist supporters and American victims. Second, military dependence from the USA is associated with more anti-American terrorism. Possibly, terrorist groups with domestic political goals deliberately attack the USA not only to counter the rise of (market)capitalism but also to raise the costs of US military support for a foreign government, which in turn is likely to weaken this government and raise the possibility of terrorist success at home (Neumayer \& Plümper, 2011). Third, per capita income is a positive predictor of terrorism. This is in line with Sanchez-Cuenca \& De La Calle (2012). Potentially, dissidents resort to antiAmerican terrorism as their main strategy in richer countries due to their inability to capture territory. By contrast, in poor countries it is more attractive for an insurgent group to seize territory and wage an open rebellion to implement an anti-market and anti-American agenda. ${ }^{1}$ Fourth, distance to the USA and democratic institutions share no statistically significant association with anti-American terrorism. Finally, with respect to the additional control variables, we find that the prevalence of domestic political instability (state failure) is robustly associated with more anti-American terrorism. This speaks to Piazza (2008) who finds that instability creates a political vacuum that facilitates terrorist activity. Government size is found to be positively related to anti-American terrorism in one specification, possibly due to rentseeking behavior by terrorist groups (Kirk, 1983).

As another robustness check, we consider whether the end of the Cold War as a major structural change in the international system affects our findings (Table 3). The end of the Cold War saw the decline of left-wing terrorism and the rise of Islamist terrorism. This development coincided to some extent with a transfer of terrorism to less developed countries, also with respect to antiAmerican terrorism (Enders \& Sandler, 2005). Potentially, these changes may have affected the role of capitalist development in explaining anti-American terrorism.

\footnotetext{
${ }^{1}$ For our sample the level of market-capitalism is rather strongly correlated with per capita income $(r=0.80)$. The collinearity diagnostics, however, suggest that our empirical findings are not affected by multicollinearity. As a robustness check, we replace per capita income with measures for domestic military spending (to indicate state capacity) and per capita energy consumption (as another measure of economic development). These variables correlate less strongly with the level of market-capitalism. As reported in the online appendix, using these variables instead of per capita income does not alter the findings reported in the main text.
} 


\begin{tabular}{|c|c|c|c|c|c|c|c|c|}
\hline & $(1)$ & $(2)$ & $(3)$ & (4) & $(5)$ & (6) & (7) & $(8)$ \\
\hline Market-Capitalist & -0.453 & -0.232 & 0.636 & 0.793 & & & & \\
\hline Development (Level-Effect) ${ }_{t-1}$ & $(0.167)^{* * *}$ & $(0.123)^{*}$ & $(0.106)^{* * *}$ & $(0.097)^{*}$ & & & & \\
\hline Market-Capitalist & 0.520 & 0.597 & 1.682 & 1.817 & & & & \\
\hline Development (Rate-of-Change-Effect) ${ }_{t-1}$ & $(0.239) * *$ & $(0.324)^{*}$ & $(0.403)^{* *}$ & $(0.588)^{*}$ & & & & \\
\hline Economic Globalization & & & & & -0.037 & -0.008 & 0.964 & 0.992 \\
\hline$(\text { Level-Effect })_{t-1}$ & & & & & $(0.014)^{* *}$ & $(0.013)$ & $(0.014)^{* *}$ & $(0.013)$ \\
\hline Economic Globalization & & & & & -0.089 & -0.001 & 0.917 & 0.999 \\
\hline${\text { (Rate-of-Change-Effect })_{t-1}}$ & & & & & $(0.060)$ & $(0.032)$ & $(0.055)$ & $(0.032)$ \\
\hline Population Size $_{t-1}$ & 0.610 & 0.685 & 1.841 & 1.984 & 0.533 & 0.802 & 1.704 & 2.231 \\
\hline & $(0.126)^{* * *}$ & $(0.117)^{* * *}$ & $(0.232)^{* * *}$ & $(0.232) * * *$ & $(0.114)^{* * *}$ & $(0.139) * * *$ & $(0.195) * * *$ & $(0.310)^{* * *}$ \\
\hline Distance to the USA & -0.388 & 0.088 & 0.678 & 1.092 & -0.192 & 0.120 & 0.825 & 1.127 \\
\hline & $(0.554)$ & $(0.110)$ & $(0.376)$ & $(0.120)$ & $(0.145)$ & $(0.100)$ & $(0.120)$ & $(0.112)$ \\
\hline GDP p.c. $t-1$ & 1.396 & 0.353 & 4.039 & 1.423 & 1.072 & 0.326 & 2.920 & 1.386 \\
\hline & $(0.227) * * *$ & $(0.244)$ & $(0.916) * * *$ & $(0.347)$ & $(0.220)^{* * *}$ & $(0.260)$ & $(0.641)^{* * *}$ & $(0.360)$ \\
\hline Democracy $_{t-1}$ & 0.029 & -0.190 & 1.029 & 0.827 & 0.369 & -0.525 & 1.446 & 0.592 \\
\hline & $(0.348)$ & $(0.296)$ & $(0.358)$ & $(0.245)$ & $(0.305)$ & $(0.348)$ & $(0.441)$ & $(0.206)$ \\
\hline Military Dependence & 0.274 & 0.237 & 1.315 & 1.267 & 0.371 & 0.352 & 1.449 & 1.422 \\
\hline from the USA $t-1$ & $(0.062) * * *$ & $(0.080)^{* * *}$ & $(0.081)^{* * *}$ & $(0.101)^{* * *}$ & $(0.063)^{* * *}$ & $(0.103) * * *$ & $(0.091) * * *$ & $(0.147)^{* * *}$ \\
\hline Sample & Cold War & $\begin{array}{l}\text { Post-Cold } \\
\text { War }\end{array}$ & Cold War & $\begin{array}{l}\text { Post-Cold } \\
\text { War }\end{array}$ & Cold War & $\begin{array}{l}\text { Post-Cold } \\
\text { War }\end{array}$ & Cold War & $\begin{array}{l}\text { Post-Cold } \\
\text { War }\end{array}$ \\
\hline No. of Countries & 126 & 149 & 126 & 149 & 115 & 136 & 115 & 136 \\
\hline No. of Observations & 2083 & 2373 & 2083 & 2373 & 1975 & 1966 & 1975 & 1966 \\
\hline Mean VIF & 1.74 & 1.73 & 1.74 & 1.73 & 1.54 & 1.56 & 1.54 & 1.56 \\
\hline Wald $\chi^{2}$ & 217.48 & 161.08 & 217.48 & 161.08 & 266.23 & 150.20 & 266.23 & 150.20 \\
\hline (Prob. $\left.>\chi^{2}\right)$ & $(0.00)^{* * *}$ & $(0.00)^{* * *}$ & $(0.00)^{* * *}$ & $(0.00) * * *$ & $(0.00)^{* * *}$ & $(0.00) * * *$ & $(0.00)^{* * *}$ & $(0.00)^{* * *}$ \\
\hline Log-Pseudolikelihood & -1230.92 & -1012.03 & -1230.92 & -1012.03 & -1071.46 & -784.18 & -1071.46 & -784.18 \\
\hline
\end{tabular}

\section{Table 3: Capitalist Development and Anti-American Terrorism during and after the Cold War}


In line with Enders \& Sandler (2005), we find evidence that anti-American terrorism transferred to less developed countries after the end of the Cold War, as per capita income is no longer a significant predictor. Our results, however, do not indicate that the end of the Cold War mattered to the role of capitalism in explaining anti-American terrorism. We still find that economic globalization and liberalization tend to share no robust association with the patterns of antiAmerican terrorism. These associations are again not economically substantive according to the IRR (Models 7 and 8 in Table 3). By contrast, there is still evidence of significant and substantive positive level-effects of market-capitalist development and negative rate-of-changeeffects of marketization for the Cold War and post-Cold War era. According to the IRR (Models 3 and 4 in Table 3), a one-unit increase in the level of market-capitalism (change in marketcapitalism) is associated with a 36 percent decrease (68 percent increase) in anti-American terrorism during the Cold War. After the end of the Cold War, a one-unit increase in the level of market-capitalism (change in market-capitalism) yields a 21 percent reduction (81 percent increase) in terrorism. This suggests that both left-wing and religious-fundamentalist extremism following the "Islamic revival" - both anti-market ideologies that have spawned anti-American terrorism — can be (at least partly) understood as reactions to the transition towards marketcapitalism, as also argued by Mousseau (2002-2003).

\section{Further Time-Series Evidence at the System Level}

\subsection{Motivation}

The evidence presented in the previous section suggests that higher levels of market-capitalism lead to less anti-American terrorism, whereas the marketization process results in more antiAmerican attacks. By contrast, there is little evidence linking higher levels of economic globalization and external liberalization to anti-American terrorism. These effects were identified at the country-level, which is the standard approach to study the origins of anti-American terrorism. However, it has also been suggested that an analysis at the system-level may prove helpful by conceptualizing anti-American terrorism as a "systemic disturbance [...] to disrupt the global order" (Volgy, Imwalle \& Corntassel, 1997: 208-209). ${ }^{1}$ With respect to the capitalismterrorism nexus, following such a view anti-American terrorism can be understood as a violent systemic response to the existing global order characterized by US-led globalization and marketization. In line with our previously outlined hypotheses, we expect a higher global level of economic globalization and/or market-capitalism to correspond with less anti-American

\footnotetext{
1 System-level studies of terrorism argue that variation at the system-level (i.e., structural determinants) rather than country-level explains the patterns of terrorism. Examples of systemlevel analyses of terrorism are O'Brien (1996), Volgy, Imwalle \& Corntassel (1997) and Sobek $\&$ Braithwaite (2005). Among the factors contributing to the emergence of terrorism considered in these studies are the involvement of countries (especially the USA and its main rivals) in foreign policy crises, the global strength of the USA and its competitors and the global support for US leadership.
} 
terrorism, while a global transition towards economic liberalization and/or market institutionalization ought to result in more anti-American terrorism.

Analyzing the relationship between capitalism and anti-American terrorism from a systemic perspective ought to complement the panel evidence reported beforehand. For instance, consider anti-American terrorism in Western Europe. In this part of the world anti-American terrorism was particularly prominent in the 1970s and 1980s, being carried out primarily by left-wing groups (e.g., the Belgian Cellules Communistes Combattantes). Many Western European countries - at least during our observation period - were characterized by already high levels of capitalist development (both in terms of economic openness and market-capitalism), making it rather unlikely that terrorist groups in many of these countries attacked the USA to prevent the further liberalization and/or marketization of their own societies. Yet, the rise of capitalism may have motivated their activities after all, albeit from a systemic rather than domestic perspective. Left-wing terrorist groups in the Western world saw their anti-American activities as part of a global struggle against US imperialism and capitalism (e.g., Varon, 2004). A system-level analysis could help to unearth such linkages.

\subsection{Data and Methodology}

We collect system-aggregated data for the period between 1970 and 2007. ${ }^{2}$ As before, data on anti-American terrorism and capitalist development come from ITERATE, the KOF Globalization Index and the Contract Intensity of National Economies Dataset. Anti-American terrorism is measured by the annual global count of transnational terrorist attacks against US interests. The global average of the KOF index indicates the systemic level of economic globalization, while the change in this variable between two years indicates global economic liberalization. Similarly, the (logged) global average of annually aggregated per capita life insurance contracts in force corresponds to the systemic level of market-capitalist development in a given year, while the change in this variable between two years indicates global marketization.

To account for other systemic factors potentially influencing the patterns of anti-American terrorism, we follow Sobek \& Braithwaite (2005) by controlling for American dominance, the power differential between the USA and the rest of the world, the preference congruence between the USA and the rest of the world and the Cold War era. The operationalization of these variables follows Sobek \& Braithwaite (2005) and is documented in the appendix.

As O'Brien (1996) and Sobek \& Braithwaite (2005), we estimate a series of ARMAX models to examine the systemic influence of capitalist development on anti-American terrorism (net of the impact of the controls). In ARMAX models the disturbances are allowed to follow a linear autoregressive (AR) moving-average (MA) specification, while the model can also consider a vector of independent control variables $(\mathrm{X}) .{ }^{3} \mathrm{ARMAX}$ models are especially suited to modelling

\footnotetext{
2 The summary statistics are reported in the appendix.

${ }^{3}$ ARMAX models are discussed in more detail in Enders (2010).
} 
time dependence which ought to matter to our analysis, given that the annual terrorism observations are unlikely to be independent from each other. By accounting for time dependence, we minimize the potential for underestimating standard errors which would otherwise affect hypothesis testing. Furthermore, we use robust standard errors because the use of a count variable as a regressand may violate (e.g., in the form of heteroskedasticity) the ARMAX assumption of normally distributed disturbances. Finally, Sobek \& Braithwaite (2005: 144) argue that ARMAX models have good small sample properties, so that the small number of observations $(T=37)$ is less likely to affect inferences.

\subsection{Empirical Findings}

The ARMAX regression results are reported in Table 4. Overall, the system-level evidence is very much in line with our country-level panel analysis findings. First, we find that economic globalization and liberalization share little relationship with the global patterns of anti-American terrorism. There is thus no support for hypotheses $H 1 a$ and $H 2 a$. By contrast, $H 1 b$ and $H 2 b$ are also buttressed by the system-level evidence. We find that a higher global level of marketcapitalism is associated with fewer anti-American incidents. At the same time, however, a transition towards market-capitalism results in more anti-American terrorism.

With respect to control variables, our findings resemble those reported by Sobek \& Braithwaite (2005). First, we find that anti-American terrorism increases with American dominance. This suggests that dominance makes it more difficult for revisionist actors to change the status quo through conventional means, making terrorism a more attractive option. Second, a higher power differential between the USA and the rest of the world tends to lead to more anti-American terrorism. Presumably, stronger differences in military capacity invite anti-American terrorism because they coincide with greater levels of dissatisfaction among weaker actors in the system, while also limiting the possibilities of changing the status quo conventionally. Third, a convergence of preferences between the USA and the rest of the world tends to result in a decrease in attacks. Presumably, such preference convergence coincides with less conflict and thus less need to resort to terrorism to foster political change in the international arena. Finally, we do not find that anti-American attacks were more common during the Cold War era, which is also in line with our previously reported panel analysis results (Table 3). 


\begin{tabular}{|c|c|c|c|c|c|c|c|c|c|}
\hline & (1) & $(2)$ & (3) & (4) & $(5)$ & (6) & (7) & (8) & (9) \\
\hline Global Level of Market- & -57.701 & -54.654 & -73.356 & -49.772 & & & & & -93.323 \\
\hline Capitalist Development & $(14.869) * * *$ & $(4.605)^{* * *}$ & $(20.740) * * *$ & $(23.879) * *$ & & & & & $(31.859) * * *$ \\
\hline Global Change in Market- & 219.475 & 233.157 & 246.032 & 221.901 & & & & & 217.281 \\
\hline Capitalist Development & $(106.972)^{* *}$ & $(77.520) * * *$ & $(114.465)^{* *}$ & $(100.546)^{* *}$ & & & & & $(83.505)^{* * *}$ \\
\hline Global Level of & & & & & -1.953 & -1.739 & -1.871 & -0.343 & 2.150 \\
\hline Economic Globalization & & & & & $(0.606)^{* * *}$ & $(0.381)^{* * *}$ & $(1.638)$ & $(1.251)$ & $(1.487)$ \\
\hline Global Change in & & & & & 2.822 & 0.738 & 3.001 & 8.129 & 4.359 \\
\hline Economic Globalization & & & & & $(7.032)$ & $(7.281)$ & $(8.820)$ & (17.104) & $(11.362)$ \\
\hline US Dominance & $\begin{array}{l}479.203 \\
(196.082)^{* *}\end{array}$ & $\begin{array}{l}470.383 \\
(129.250)^{* * *}\end{array}$ & $\begin{array}{l}439.184 \\
(194.431)^{* *}\end{array}$ & $\begin{array}{l}486.835 \\
(143.367)^{* * *}\end{array}$ & $\begin{array}{l}366.565 \\
(196.396) *\end{array}$ & $\begin{array}{l}358.098 \\
(139.102)^{* *}\end{array}$ & $\begin{array}{l}376.445 \\
(305.757)\end{array}$ & $\begin{array}{l}569.783 \\
(259.945)^{* *}\end{array}$ & $\begin{array}{l}635.739 \\
(202.109) * * *\end{array}$ \\
\hline Power Differential & $\begin{array}{l}122.310 \\
(73.597)^{*}\end{array}$ & $\begin{array}{l}105.826 \\
(46.384)^{* *}\end{array}$ & $\begin{array}{l}99.921 \\
(72.579)\end{array}$ & $\begin{array}{l}111.554 \\
(41.166)^{* * *}\end{array}$ & $\begin{array}{l}39.742 \\
(74.215)\end{array}$ & $\begin{array}{l}29.332 \\
(49.582)\end{array}$ & $\begin{array}{l}45.760 \\
(113.142)\end{array}$ & $\begin{array}{l}142.358 \\
(109.699)\end{array}$ & $\begin{array}{l}209.982 \\
(89.283)^{* *}\end{array}$ \\
\hline Preference Congruence & $\begin{array}{l}-116.847 \\
(18.964)^{* * *}\end{array}$ & $\begin{array}{l}-115.989 \\
(11.599) * * *\end{array}$ & $\begin{array}{l}-115.832 \\
(18.274)^{* * *}\end{array}$ & $\begin{array}{l}-116.934 \\
(11.366)^{* * *}\end{array}$ & $\begin{array}{l}-95.767 \\
(20.333)^{* * *}\end{array}$ & $\begin{array}{l}-95.329 \\
(13.250)^{* * *}\end{array}$ & $\begin{array}{l}-96.766 \\
(29.804) * * *\end{array}$ & $\begin{array}{l}-120.279 \\
(30.173) * * *\end{array}$ & $\begin{array}{l}-144.279 \\
(26.039) * * *\end{array}$ \\
\hline Cold War & & & $\begin{array}{l}-7.026 \\
(7.113)\end{array}$ & $\begin{array}{l}2.048 \\
(9.538)\end{array}$ & & & $\begin{array}{l}1.181 \\
(18.537)\end{array}$ & $\begin{array}{l}22.697 \\
(24.502)\end{array}$ & $\begin{array}{l}13.319 \\
(17.514)\end{array}$ \\
\hline $\operatorname{AR}(1)$ & $\begin{array}{l}-0.170 \\
(0.159)\end{array}$ & $\begin{array}{l}0.321 \\
(0.384)\end{array}$ & $\begin{array}{l}-0.164 \\
(0.162)\end{array}$ & $\begin{array}{l}0.312 \\
(0.374)\end{array}$ & $\begin{array}{l}-0.139 \\
(0.176)\end{array}$ & $\begin{array}{l}0.442 \\
(0.360)\end{array}$ & $\begin{array}{l}-0.143 \\
(0.230)\end{array}$ & $\begin{array}{l}0.251 \\
(0.538)\end{array}$ & $\begin{array}{l}0.179 \\
(0.436)\end{array}$ \\
\hline MA(1) & & $\begin{array}{l}-0.999 \\
(0.001)^{* * *}\end{array}$ & & $\begin{array}{l}-1.000 \\
(0.001)^{* * *}\end{array}$ & & $\begin{array}{l}-0.999 \\
(0.001) * * *\end{array}$ & & $\begin{array}{l}-1.000 \\
(0.001) * * *\end{array}$ & $\begin{array}{l}-1.000 \\
(0.001)^{* * *}\end{array}$ \\
\hline No. of Observations & 37 & 37 & 37 & 37 & 37 & 37 & 37 & 37 & 37 \\
\hline Log-Pseudolikelihood & -158.32 & -152.76 & -158.21 & -152.74 & -159.37 & -155.09 & -159.37 & -154.17 & -151.90 \\
\hline Ljung-Box Q-Statistic & 10.354 & 7.909 & 9.863 & 8.042 & 10.223 & 9.531 & 9.900 & 8.997 & 9.066 \\
\hline$\left(\right.$ Prob. $\left.>\chi^{2}\right)$ & $(0.11)$ & $(0.16)$ & $(0.13)$ & $(0.15)$ & $(0.11)$ & $(0.09)^{*}$ & $(0.13)$ & $(0.11)$ & $(0.11)$ \\
\hline AIC & 332.63 & 323.52 & 334.43 & 325.49 & 334.75 & 328.18 & 336.74 & 328.34 & 327.80 \\
\hline
\end{tabular}

Table 4: ARMAX Regression Results 


\section{Conclusion}

US President George W. Bush (2001) after the 9/11 attacks asked: "Why do they hate us?" Using data for a 149 countries for the period between 1970 and 2007, we present panel and time-series evidence suggesting that anti-American resentment is not only incited by US foreign policy but also the rise of capitalism. Importantly, though, this is only true when we conceptualize and operationalize capitalism as social market-capitalism in the sense of the economic norms theory. By contrast, there is little evidence that capitalism understood in a more classical sense as external economic openness with little government regulation shares any substantial relationship with anti-American terrorism.

Our results therefore suggests that anti-American terrorism is not rooted in economic liberalization (i.e., the opening up and deregulation of international goods and capital markets) and cannot be curtailed solely by increased interdependence that accompanies economic globalization and the economic gains induced by trade and financial openness. Rather, our findings are consistent with expectations that follow from the economic norms theory framework and suggest that anti-American terrorism has anti-market roots. In particular when economies undergo the transition from clientalism to market-capitalism, those societal groups (the old elite and their economically vulnerable clientele, traditionalists and the religious) that have benefitted from the pre-market clientalist-traditionalist order of society may intentionally target the USA to effectively voice dissent and rollback pro-market developments and punish the USA for its perceived role in capitalism, globalization and the Americanization of their societies.

Besides such destabilizing rate-of-change-effects of market-capitalist development, our findings, however, also point at beneficial level-effects. Anti-American terrorism is less likely to originate from countries that are similarly market-capitalist as the USA. Again, this is consistent with economic norms theory. Market-capitalist countries have no incentive to produce or promote terrorism directed against the USA as the most important market-capitalist economy. Rather, the USA and other market-capitalist economies share similar interests in international market growth (which benefits all of them) and in the expansion and persistence of liberal-democratic institutions that underpin a global status quo favorable to them.

The double-edged effect of market-capitalist development on anti-American terrorism has important policy implications. As previously suggested by Mousseau (2002-2003), the US may become a less likely target of transnational terrorism by (peacefully) subsidizing and propagating the establishment of market-capitalist economies. For instance, pro-market interest groups in clientalist economies may be strengthened through US support for domestic programs that foster the creation of independent judicial institutions (to allow markets to function properly) and counter corruption (to diminish the influence of the old clientalist elite). Crucially, however, the disruptive political, economic and cultural effects of the marketization process cannot be disregarded, as they may very well incite anti-American terrorism. Here, the USA may help to make the transition process as bearable as possible for groups in foreign societies that may develop anti-market resentments. For instance, the USA may help to insulate the economically 
vulnerable from the most adverse consequences of marketization by means of sound trade policy and directed development assistance that increases local economic opportunities.

\section{References}

BBC News (2003) Bin Laden tape: Text. February 12, 2003 (http://news.bbc.co.uk/2/hi/middle_east/2751019.stm).

Bush, George W (2001) Address to a Joint Session of Congress. Washington, DC, September 20, 2001.

Bussmann, Margit \& Gerald Schneider (2007). When globalization discontent turns violent: Foreign economic liberalization and internal war. International Studies Quarterly 51(1): 7997.

Cheibub, Jose A, Jennifer Gandhi \& James R Vreeland (2010) Democracy and dictatorship revisited. Public Choice 143(1-2): 67-101.

Cronin, Audrey K (2003) Behind the curve: Globalization and international terrorism. International Security 27(3): 30-58.

Dafoe, Allan, John R Oneal \& Bruce M Russett (2013) The democratic peace: Weighing the evidence and cautious inference. International Studies Quarterly 57(1): 201-214.

De Soysa, Indra \& Hanne Fjelde (2010) Is the hidden hand an iron fist? Capitalism and civil peace, 1970-2005. Journal of Peace Research 47(3): 287-298.

Dreher, Axel (2006) Does globalization affect growth? Evidence from a new index of globalization. Applied Economics 38(10): 1091-1110.

Dreher, Axel, Martin Gassebner \& Lars H R Siemers (2012) Globalization, economic freedom and human rights. Journal of Conflict Resolution 56(3): 516-546.

Enders, Walter (2010) Applied Econometric Time Series. Hoboken, NJ: John Wiley \& Sons.

Enders, Walter \& Todd Sandler (2005) Distribution of transnational terrorism among countries by income class and geography after 9/11. International Studies Quarterly 50(2): 367-393.

Gartzke, Erik (2007) The capitalist peace. American Journal of Political Science 51(1): 166-191.

Grunberg, Gerard (2005) Anti-Americanism in French and European public opinion. In: Tony Judt \& Denis Lacorne (eds.) With Us or Against Us: Studies in Global Anti-Americanism, New York: Palgrave Macmillan, 59-73.

Hegre, Havard (2000) Development and the liberal peace: What does it take to be a trading state? Journal of Peace Research 37(1): 5-30. 
Heston, Alan, Robert Summers \& Bettina Aten (2009) Penn World Table 6.3. Center for International Comparisons of Production, Income and Prices at the University of Pennsylvania.

Kirk, Richard M (1983) Political terrorism and the size of government: A positive institutional analysis of violent political activity. Public Choice 40(1): 41-52.

Krieger, Tim \& Daniel Meierrieks (2011) What causes terrorism? Public Choice 147(1-2): 3-27.

LaFree, Gary, Sue-Ming Yang \& Martha Crenshaw (2009) Trajectories of terrorism: Attack patterns of foreign groups that have targeted the United States, 1970-2004. Criminology \& Public Policy 8(3): 445-473.

Mayer, Thierry \& Soledad Zignago (2011) Notes on CEPII's distances measures: The GeoDist Database. CEPII Working Paper 2011-25.

Mickolus, Edward F, Sandler, Todd, Murdock, Jean M, Flemming, Peter A (2008) International Terrorism: Attributes of Terrorist Events, 1968-2007. Dunn Loring, VA: Vinyard Software.

Mousseau, Michael (2002-2003) Market civilization and its clash with terror. International Security 27(3): 5-29.

Mousseau, Michael (2009) The social market roots of democratic peace. International Security 33(4): 52-86.

Mousseau, Michael (2011) Urban poverty and support for Islamist terror: Survey results of Muslims in fourteen countries. Journal of Peace Research 48(1): 35-47.

Mousseau, Michael (2012) Capitalist development and civil war. International Studies Quarterly 56(3): 470-483.

Mousseau, Michael (2013) The democratic peace unraveled: It's the economy. International Studies Quarterly 57(1): 186-197.

Mousseau, Michael \& Demet Y Mousseau (2008) The contracting roots of human rights. Journal of Peace Research 45(3): 327-344.

Mousseau, Michael, Omer F Orsun, Jameson L Ungerer \& Demet Y Mousseau (2013) Capitalism and peace: It's Keynes, not Hayek. In: Gerald Schneider \& Nils P Gleditsch (eds.) Assessing the Capitalist Peace. New York: Routledge, 80-104.

Neumayer, Eric \& Indra de Soysa (2007) Globalisation, women's economic rights and forced labour. World Economy 30(10): 1510-1535.

Neumayer, Eric \& Thomas Plümper (2011) Foreign terror on Americans. Journal of Peace Research 48(1): 3-17.

O'Brien, Sean P (1996) Foreign policy crises and the resort to terrorism: A time-series analysis of conflict linkages. Journal of Conflict Resolution 40(2): 320-335. 
Pape, Robert A (2003) The strategic logic of suicide terrorism. American Political Science Review 97(3): 343-361.

Piazza, James A (2008) Incubators of terror: Do failed and failing states promote transnational terrorism? International Studies Quarterly 52(3): 469-488.

Sanchez-Cuenca, Ignacio \& Luis De La Calle (2012) Rebels without a territory: An analysis of nonterritorial conflict in the world, 1970-1997. Journal of Conflict Resolution 56(4): 580-603.

Schneider, Gerald \& Nils P Gleditsch (2010) The capitalist peace: The origins and prospects of a liberal idea. International Interactions 36(2): 107-114.

Schneider, Gerald (2014) Peace through globalization and capitalism? Prospects of two liberal propositions. Journal of Peace Research 51(2): 173-183.

Singer, J David (1988) Reconstructing the Correlates of War Dataset on material capabilities of states, 1816-1985. International Interactions 14(2): 115-132.

Sobek, David M \& Alex Braithwaite (2005) Victims of success: American dominance and terrorism. Conflict Management and Peace Science 22(2): 135-148.

Stiglitz, Joseph E (2005) The overselling of globalization. In: Michael M. Weinstein (ed.) Globalization: What's New. New York: Columbia University Press: New York, 228-261.

USAID (2013) U.S. Overseas Loans and Grants Online (http://gbk.eads.usaidallnet.gov/data/detailed.html).

Varon, Jeremy (2004) Bringing the War Home: The Weather Underground, the Red Army Faction, and Revolutionary Violence in the Sixties and Seventies. Berkeley and Los Angeles: University of California Press.

Volgy, Thomas J, Lawrence E Imwalle \& Jeff J Corntassel (1997) Structural determinants of international terrorism: The effects of hegemony and polarity on terrorist activity. International Interactions 23(2): 207-231. 


\section{Supplementary Material}

\begin{tabular}{|c|c|c|c|c|c|}
\hline Variable & $\mathrm{N} * \mathrm{~T}$ & Mean & SD & Min. & Max. \\
\hline $\begin{array}{l}\text { Anti-American Terrorist } \\
\text { Attacks }\end{array}$ & 5105 & 0.342 & 1.884 & 0 & 88 \\
\hline $\begin{array}{l}\text { Market-Capitalist } \\
\text { Development (Level) }\end{array}$ & 5043 & 3.017 & 1.714 & 0.131 & 9.021 \\
\hline $\begin{array}{l}\text { Market-Capitalist } \\
\text { Development (Change) }\end{array}$ & 4894 & 0.028 & 0.190 & -2.704 & 2.723 \\
\hline $\begin{array}{l}\text { Economic Globalization } \\
\text { Index (Level) }\end{array}$ & 4648 & 48.381 & 19.407 & 9.425 & 96.826 \\
\hline $\begin{array}{l}\text { Economic Globalization } \\
\text { Index (Change) }\end{array}$ & 4512 & 0.686 & 2.269 & -16.779 & 19.396 \\
\hline Population Size (log) & 5105 & 9.062 & 1.500 & 4.824 & 14.095 \\
\hline Distance to USA (log) & 5104 & 8.396 & 1.120 & 0 & 9.155 \\
\hline GDP p.c. $(\log )$ & 5104 & 8.455 & 1.162 & 5.032 & 11.491 \\
\hline Democracy & 5105 & 0.416 & 0.493 & 0 & 1 \\
\hline $\begin{array}{l}\text { Military Dependence from } \\
\text { USA }(\log +1)\end{array}$ & 4909 & 1.365 & 1.786 & 0 & 10.142 \\
\hline Government Size & 5104 & 18.269 & 9.866 & 1.438 & 83.350 \\
\hline State Failure & 5100 & 0.632 & 1.707 & 0 & 13.5 \\
\hline
\end{tabular}

Supplementary Table 1: Summary Statistics (Panel Data) 


\begin{tabular}{|c|c|c|c|c|}
\hline & (1) & (2) & (3) & (4) \\
\hline Market-Capitalist & -0.329 & & -0.279 & \\
\hline Development (Level-Effect) ${ }_{t-1}$ & $(0.112) * * *$ & & $(0.112)^{* * *}$ & \\
\hline Market-Capitalist & 0.446 & & 0.417 & \\
\hline Development (Rate-of-Change-Effect) ${ }_{t-1}$ & $(0.206)^{* *}$ & & $(0.243)^{*}$ & \\
\hline Economic Globalization & & -0.015 & & -0.012 \\
\hline$(\text { Level-Effect })_{t-1}$ & & $(0.011)$ & & $(0.009)$ \\
\hline Economic Globalization & & -0.001 & & 0.003 \\
\hline (Rate-of-Change-Effect) ${ }_{t-1}$ & & $(0.024)$ & & $(0.025)$ \\
\hline Population Size $_{t-1}$ & 0.643 & 0.672 & 0.622 & 0.676 \\
\hline & $(0.093) * * *$ & $(0.098)^{* * *}$ & $(0.101)^{* * *}$ & $(0.1403)^{* * *}$ \\
\hline Distance to the USA & -0.123 & -0.066 & -0.231 & -0.154 \\
\hline & $(0.197)$ & $(0.119)$ & $(0.236)$ & $(0.151)$ \\
\hline GDP p.c. $t-1$ & 0.751 & 0.566 & & \\
\hline & $(0.190)^{* * *}$ & $(0.179)^{* * *}$ & & \\
\hline Democracy $_{t-1}$ & -0.040 & 0.019 & 0.268 & 0.260 \\
\hline & $(0.235)$ & $(0.226)$ & $(0.257)$ & $(0.235)$ \\
\hline Domestic Military Spending p.c. $t-1$ & & & 0.449 & 0.322 \\
\hline & & & $(0.095) * * *$ & $(0.102)^{* * *}$ \\
\hline Energy Consumption p.c. $t-1$ & & & 0.013 & 0.028 \\
\hline & & & $(0.033)$ & $(0.035)$ \\
\hline Military Dependence & 0.257 & 0.335 & 0.277 & 0.339 \\
\hline from the USA $_{t-1}$ & $(0.054) * * *$ & $(0.055)^{* * *}$ & $(0.055) * * *$ & $(0.057) * * *$ \\
\hline No. of Observations & 4576 & 4277 & 4576 & 4277 \\
\hline No. of Countries & 149 & 136 & 149 & 136 \\
\hline Mean VIF & 1.71 & 1.48 & 1.51 & 1.38 \\
\hline Wald $\chi^{2}$ & 371.99 & 357.09 & 388.84 & 341.12 \\
\hline$\left(\right.$ Prob. $\left.>\chi^{2}\right)$ & $(0.00) * * *$ & $(0.00) * * *$ & $(0.00) * * *$ & $(0.00) * * *$ \\
\hline Log-Pseudolikelihood & -2374.38 & -2118.60 & -2375.85 & -2120.56 \\
\hline \multicolumn{5}{|c|}{$\begin{array}{l}\text { Notes: not reported. All models include year dummies (not reported). Robust standard errors } \\
\text { clustered over countries in parentheses. Models (1) and (2) report findings in Table } 2 \text { for the sake } \\
\text { of comparison. } * \mathrm{p}<0.10, * * \mathrm{p}<0.05, * * * \mathrm{p}<0.01 \text {. }\end{array}$} \\
\hline
\end{tabular}

Supplementary Table 2: Capitalist Development and Anti-American Terrorism (Per Capita Income Replaced) 


\begin{tabular}{|c|c|c|c|c|c|c|}
\hline Variable & $\mathrm{N} * \mathrm{~T}$ & Mean & SD & Min. & Max. & Operationalization \\
\hline $\begin{array}{l}\text { Global Anti-American } \\
\text { Terrorist Attacks }\end{array}$ & 38 & 45.895 & 22.799 & 14 & 121 & \\
\hline $\begin{array}{l}\text { Global Level of Market- } \\
\text { Capitalist Development }\end{array}$ & 38 & 2.991 & 0.281 & 2.603 & 3.582 & \\
\hline $\begin{array}{l}\text { Global Change in Market- } \\
\text { Capitalist Development }\end{array}$ & 37 & 0.026 & 0.024 & -0.026 & 0.100 & \\
\hline $\begin{array}{l}\text { Global Level of Economic } \\
\text { Globalization }\end{array}$ & 38 & 47.764 & 7.433 & 38.155 & 62.732 & \\
\hline $\begin{array}{l}\text { Global Change in Economic } \\
\text { Globalization }\end{array}$ & 37 & 0.664 & 0.459 & -0.208 & 1.794 & \\
\hline Power Differential & 38 & -0.010 & 0.029 & -0.056 & 0.051 & $\begin{array}{l}C I N C \text { score for the USA minus the } C I N C \text { score of the chief } \\
\text { revisionist power (see notes for details) }\end{array}$ \\
\hline $\begin{array}{l}\text { Preference Congruence with } \\
\text { USA }\end{array}$ & 38 & -0.186 & 0.243 & -0.551 & 0.294 & $\begin{array}{l}\text { Mean affinity score between the USA and the other members } \\
\text { of the United Nations (see notes for details) }\end{array}$ \\
\hline Dominance & 38 & -0.067 & 0.033 & -0.144 & 0 & $\begin{array}{l}\text { Product of the CINC score and affinity score of the chief } \\
\text { revisionist power of the USA (see notes for details) }\end{array}$ \\
\hline Cold War & 38 & 0.526 & 0.506 & 0 & 1 & Dummy variable for the $1970-1989$ period. \\
\hline \multicolumn{7}{|c|}{$\begin{array}{l}\text { Notes: CINC (Composite Index of National Capability) score drawn from an update of Singer (1987). The CINC score is a composite index } \\
\text { indicating a country's demographic, economic and military strength (e.g., in terms of population size, energy consumption and military } \\
\text { personnel). Chief revisionist power is the country with the combination of the highest CINC score and lowest affinity with the United States } \\
\text { at a given year (USSR/Russia in 1970-1971 and 1977-1990; China in 1972-1976 and from 1991-2007). Affinity reflects the similarity of state } \\
\text { preferences based on their voting positions in the UN General Assembly. The affinity data is taken from the Affinity of Nations Datase } \\
\text { (http://dss.ucsd.edu/ egartzke/htmlpages/data.html). }\end{array}$} \\
\hline
\end{tabular}

Supplementary Table 3: Summary Statistics and Variable Operationalization (Time-Series Data) 
List of Countries

\begin{tabular}{|c|c|c|c|c|}
\hline Afghanistan & Congo (DR) & Haiti & Mexico & Slovak Republic \\
\hline Albania & Costa Rica & Honduras & Moldova & Slovenia \\
\hline Algeria & Cote d'Ivoire & Hungary & Mongolia & Somalia \\
\hline Angola & Croatia & India & Morocco & South Africa \\
\hline Argentina & Cuba & Indonesia & Mozambique & South Korea \\
\hline Armenia & Cyprus & Iran & Namibia & Spain \\
\hline Australia & Czech Republic & Iraq & Nepal & Sri Lanka \\
\hline Austria & Denmark & Ireland & Netherlands & Sudan \\
\hline Azerbaijan & Djibouti & Israel & New Zealand & Swaziland \\
\hline Bahrain & Dominican Republic & Italy & Nicaragua & Sweden \\
\hline Bangladesh & Ecuador & Jamaica & Niger & Switzerland \\
\hline Belarus & Egypt & Japan & Nigeria & Syria \\
\hline Belgium & El Salvador & Jordan & Norway & Tajikistan \\
\hline Benin & Equatorial Guinea & Kazakhstan & Oman & Tanzania \\
\hline Bolivia & Eritrea & Kenya & Pakistan & Thailand \\
\hline Bosnia \& Herzegovina & Estonia & Kuwait & Panama & Togo \\
\hline Botswana & Ethiopia & Kyrgyzstan & Papua New Guinea & Trinidad \& Tobago \\
\hline Brazil & Fiji & Laos & Paraguay & Tunisia \\
\hline Bulgaria & Finland & Latvia & Peru & Turkey \\
\hline Burkina Faso & France & Lebanon & Philippines & Uganda \\
\hline Burundi & Gabon & Lesotho & Poland & Ukraine \\
\hline Cambodia & Gambia & Liberia & Portugal & United Arab Emirates \\
\hline Cameroon & Georgia & Lithuania & Qatar & United Kingdom \\
\hline Canada & Germany & Macedonia & Romania & Uruguay \\
\hline Central African Republic & Ghana & Madagascar & Russia & Uzbekistan \\
\hline Chad & Greece & Malawi & Rwanda & Venezuela \\
\hline Chile & Guatemala & Malaysia & Saudi Arabia & Yemen \\
\hline China & Guinea & Mali & Senegal & Zambia \\
\hline Colombia & Guinea-Bissau & Mauritania & Sierra Leone & Zimbabwe \\
\hline Congo & Guyana & Mauritius & Singapore & \\
\hline
\end{tabular}

